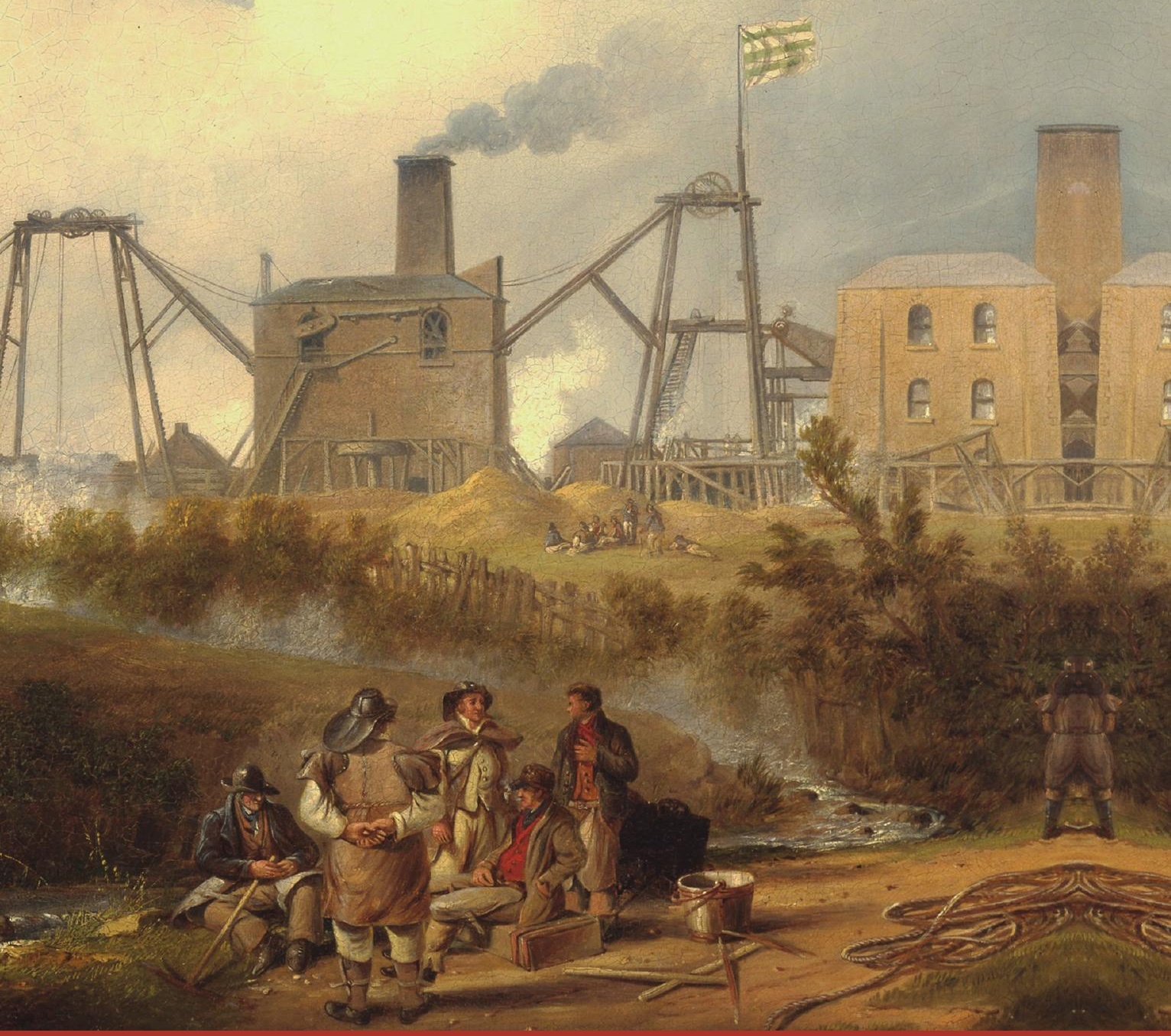

Disability in the Industrial Revolution

Physical impairment in British coalmining, 1780-1880

DAVID M.TURNER AND DANIEL BLACKIE 


\section{DISABILITY IN THE INDUSTRIAL REVOLUTION}

\section{MANCHESTER 1824}

Manchester University Press 


\title{
DISABILITY
HISTORY
}

\author{
Series editors \\ Dr Julie Anderson, Professor Walton Schalick, III
}

This new series published by Manchester University Press responds to the growing interest in disability as a discipline worthy of historical research. The series has a broad international historical remit, encompassing issues that include class, race, gender, age, war, medical treatment, professionalisation, environments, work, institutions and cultural and social aspects of disablement including representations of disabled people in literature, film, art and the media.

\section{Already published}

Deafness, community and culture in Britain: leisure and cohesion, 1945-1995 Martin Atherton

Rethinking modern prostheses in Anglo-American commodity cultures, 1820-1939

Claire L. Jones (ed.)

Destigmatising mental illness? Professional politics and public education in Britain, I870-1970

Vicky Long

Intellectual disability: a conceptual history, I200-1900

Patrick McDonagh, C. F. Goodey and Tim Stainton (eds)

Fools and idiots? Intellectual disability in the Middle Ages

Irina Metzler

Framing the moron: the social construction of feeble-mindedness in the

American eugenics era

Gerald V. O'Brien

Recycling the disabled: army, medicine, and modernity in WWI Germany Heather R. Perry

Worth saving: disabled children during the Second World War

Sue Wheatcroft 


\title{
DISABILITY IN THE INDUSTRIAL REVOLUTION
}

\section{PHYSICAL IMPAIRMENT IN BRITISH COALMINING, I780-1880}

\author{
David M. Turner and Daniel Blackie
}

Manchester University Press 
Copyright (c) David M. Turner and Daniel Blackie 2018

The rights of David M. Turner and Daniel Blackie to be identified as the authors of this work have been asserted by them in accordance with the Copyright, Designs and Patents Act 1988.

This electronic version has been made freely available under a Creative Commons (CC-BYNC-ND) licence, thanks to the support of the Wellcome Trust. A copy of the licence can be viewed at https://creativecommons.org/licenses/by-nc-nd/4.0/

Published by Manchester University Press

Altrincham Street, Manchester M1 7JA

www.manchesteruniversitypress.co.uk

British Library Cataloguing-in-Publication Data

A catalogue record for this book is available from the British Library

ISBN 9781526118158 hardback

ISBN 9781526125774 open access

First published 2018

The publisher has no responsibility for the persistence or accuracy of URLs for any external or third-party internet websites referred to in this book, and does not guarantee that any content on such websites is, or will remain, accurate or appropriate.

Typeset in 10/12pt Arno Pro by

Servis Filmsetting Ltd, Stockport, Cheshire 